\title{
PENERAPAN PENDIDIKAN REVOLUSI MENTAL DALAM PEMBENTUKAN KARAKTER
}

\author{
Dewi Suminar'1, Nandy Mulya, M.Pd² \\ ${ }^{1,2}$ Pendidikan Sosiologi, Universitas Sultan Ageng Tirtayasa \\ correspondence email: dewisuminar1298@gmail.com
}

Received : 18 June, 2020

Revised : 20 June, 2020

Accepted: 22 June, 2020

\begin{abstract}
ABSTRAK
Penerapan revolusi mental di lakukan oleh pemerintah dan masyarakat guna memperbaiki moral masyarakat indonesia fokus penerapan revolusi mental ini dalam ranah pendidikan. Tujuan dari studi ini adalah menganalisa implementasi penerapan pendidikan karakter dalam membentuk karakter siswa. Studi ini menggunakan metodologi meta-analisis yang melibatkan beberapa karya tulis ilmiah yang berhubungan dengan penerapan pendidikan revolusi mental dalam membentuk karakter siswa, dengan menggunakan teori moralitas Durkheim. Tujuan dari penulisan ini adalah untuk mengetahui sejauh mana penerapan dari revolusi mental di lakukan dan seberapa besar pengaruh revolusi mental dalam membentuk karakter siswa.
\end{abstract}

Kata kunci: pendidikan, revolusi mental, karakter

\begin{abstract}
The application of mental revolution is carried out by the government and the community in order to improve the morale of Indonesian society. The focus of the application of mental revolution is in the realm of education. The purpose of this study is to analyze the implementation of the application of character education in shaping the character of students. This study uses a meta-analysis methodology that involves several scientific papers related to the application of mental revolution education in shaping student character, using Durkheim's theory of morality. The purpose of this paper is to determine the extent of the application of the mental revolution and how much influence the mental revolution has in shaping the character of students.
\end{abstract}

Keywords: education, mental revolution, character 


\section{PENDAHULUAN}

Revolusi mental sangat penting di lakukan mengingat banyak kasus atau peristiwa yang terjadi pada anak bangsa yang berstatus siswa melakukan tindakan yang menyalahi aturan dan norma yang ada, belum lagi fenomena antara guru dan murid yang belakangan ini sering terjadi entah itu penganiayaan ataupun penyimpangan yang di lakukan siswa terhadap gurunya. Revolusi mental sedang gencar-gencarnya diterapkan di Indonesia khususnya dalam bidang pendidikan, hal itu tentunya melibatkan kurikulum pendidikan ikut berubah dan memuat nilai-nilai revolusi mental agar terimplementasikan kedalam proses pembelajaran dan bersikap sehari-hari.

Nilai-nilai revolusi mental sudah termuat dalam kurikulum pendidikan, tinggal penerapannya yang harus terus di lakukan, penerapan nilai-nilai revolusi mental tidak hanya sehari atau dua hari di implementasikannya tapi seterusnya sampai sikap dan sifat tersebut menjadi suatu kebiasaan siswa dan tentunya itu yang menjadi tujuan dari revolusi mental ini di lakukan , agar siswa memiliki kebiasaan yang baik dan tentutunya tidak menyalahi aturan dan norma yang berlaku.

Dalam UU RI Nomor 20 Tahun 2003 tentang sisdiknas bab II pasal (3) berisikan bahwa fungsi dari pendidikan nasional yaitu mengembangkan kemampuan dan membentuk karakter yang bermartabat untuk mencerdaskan kehidupan bangsa.

Durkheim menyatakan bahwa pendidikan akan membantu untuk berkepribadian baik atau memiliki moral agar dapat berinterkasi baik dengan masyarakat, dan dia percaya bahwa sekolah adalah alat satu-satunya yang memberikan dasar pembentukan moral. Bagi Durkheim, ruang sekolah merupakan tempat menumbuhkan kesadaran kolektif untuk menanamkan moral. Dari beragamnya penghuni ruang kelas maka akan beragam pula moral yang terbentuk. Hal tersebut tentunya akan sangat memungkinkan pendidikan memproduksi semua elemen moralitas.

Moralitas berfungsi sebagai pembatas agar individu tidak melakukan tindakan yang terlarang. Membatasi individu merupakan sasaran dari moralitas, sistem larangan dalam moralitas adalah komprehensif dengan adanya moralitas dapat mengendalikan tindakan atau perilaku individu agar berlangsung normal dan tidak menciderai moral dan nilai yang berlaku di masyarakat. (Juanda, sastra at.al. 2019:82)

Moralitas menurut Durkheim, memiliki tiga elemen, pertama moralitas mengenai disiplin, Durkheim selalu berbicara tentang disiplin dari sudut pandang sistem/ aturan yang mengekang seseorang terhaadap keinginan sebenarnya seseorang itu, karena menurut Durkheim keinginan seseorang dalam kelompok dengan keinginan individunya pasti berbeda dan itu yang akan menciptakan konflik, maka dari itu individu tersebut harus bertanggung 
jawab moral terhadap kelompok atas dirinya. Secara garis besar displin sosial dapat menengkan karena sifat mengekang dan membatasi keinginan individu dan memberikan kesempatan kepada individu untuk merasa puas dan tenang dan tidak menuntut lebih.

Kedua, keterikatan terhadap kelompok sosial-kehangatan, keterikatan terhadap kelompok sosial disini bukan karena paksaan dan maksud tertentu tetapi karena keterikatan atas dasar ketulusan,kedua elemen disiplin dan keterikatan saling menyempurnakan karena keduanya merupakan elemen yang berbeda, jika disiplin merupakan elemen yang mengekang/membatasi kita, sedangkan elemen keterikatan merupakan elemen bagian dari kita.

Ketiga, elemen ketiga dari moralitas menurut Durkheim adalah otonomi moral, elemen otonomi memiliki kekuatan penuh dalam modernitas, otonomi moral ini akan menyempurnakan kedua elemen sebelumnya yaitu, disiplin dan keterikatan, dengan adanya otonomi moral . menurut Durkheim satu-satunya elemen yang dapat membuat faham akan moralitas adalah "pendidikan". (ritzer, 114-115:2012)

Usaha Durkheim dalam menegakan reformasi masyarakat agar moralitas modern dapat di implementasikan yaitu dengan mangaitkan pendidikan, pendidikan menurut Durkheim sebagai proses individu bisa mendapatkan alat-alat fisik, intelektual dan moral agar dapat berperan dalam masyarakat. Sebelum melakukan reformasi pendidikan.

Durkheim menyatakan ada dua pendekatan yang ia gunakan, pertama pendidikan merupakan perpanjangan tangan gereja yang berarti pendidikan merupakan tempat lain yang dapat memberikan pemahaman/ilmu agama yang tersalurkan dari gereja, kedua Durkheim menyatakan bahwa pendiidkan merupakan pembentukan karakter/ pencetak kepribadian yang alami karena proses di dalam pendidikan tersebut dapat membentuk individu sesuai yang ia lewati, berbeda proses pendidikannya, maka akan berbeda pula bentukannya.

Menurut Durkheim pendidikan dapat memberikan individu yang di dalamnya disiplin-disiplin yang di perlukan untuk mengelola keinginan yang dapat mencelakakan mereka. Yang kedua pendidikan menurut Durkheim dapat menimbulkan rasa pengabdian terhadap masyarakat dan moralnya di dalam setiap diri peserta didik. Yang terpenting adalah pendidikan berperan sebagai pengembangan otonomi, dimana disiplin didambakan secara tulus dan keterikatan masyarakat berdasarkan pada persetujuan. (ritzer, 114-115:2012) 


\section{METODE}

Metode yang digunakan dalam studi ini adalah metode studi pustaka/literature. Menurut Burhan Bungin Metode literatur adalah salah satu metode pengumpulan data yang digunakan dalam metodologi penelitian sosial untuk menelusuri data historis. Sedangkan Sugiyono menyatakan bahwa kajian literatur merupakan catatan peristiwa yang sudah berlalu yang berbentuk tulisan, gambar, atau karya-karya monumental dari seseorang"'

Pendekatan dalam penelitian ini menggunakan pendekatan dekriptif kualitatif, karena permasalahan yang holistik, kompleks, dinamis dan penuh makna. Selain itu, peneliti bermaksud memahami situasi sosial secara mendalam, menemukan pola, hipotesis dan teori.

Teknik pengumpulan data menggunakan kajian literatur dengan mempelajari dan melakukan pencatatan dengan sistem fenomena-fenomena yang diselidiki, atau kata hain adalah pengumpulan data yang dilakukan dengan cara mengamati dan mencatat secara sistematik referensi / fenomena yang ada.

Dengan demikian, penelitian kepustakaan adalah serangkaian kegiatan yang berkenaan dengan metode pengumpulan data pustaka, membaca dan mencatat serta mengolah bahan penelitian

\section{PEMBAHASAN}

Didalam teori moralitas dan pendidikan moral membahas elemen-elemen yang dapat membentuk moral yang menjadi keperibadian anak dan itu terbentuk didalam ruang kelas yang memiliki elemen-elemen pembentukan sikap disiplin dimana sikap displin ini yang dapat membatasi diri anak melakukan hal-hal yang melanggar norma pada masa kini disiplin merupakan salah satu pendidikan revolusi mental dan pendidikan karakter yang dapat membentuk moral. dan di dalam teori moralitas Durkheim menyatakan bahwa dalam pembentukan moral tidak boleh adanya paksaan harus secara tulus elemen disiplin dan keterikatan ini dapat membentuk moral yang baik dimana sikap disiplin dapat membatasi sebagai kekangan dan keterikatan merupakan ketulusan diri untuk tidak melakukan hal-hal di luar norma. Terakhir elemen otonomi moral yang menyempurnakan kedua elemen tersebut.

Durkheim juga menyatakan bahwa pendidikan dapat membentuk moral dan membuat anak lebih baik dalam berinteraksi dengan masyarakat. didalam interaksi yang terjadi di ruang lingkup sekolah dapat menumbuhkan kesadaran kolektif yang dapat membentuk moral anak, dalam penerapan pendidikan revolusi mental yang berfokus pada ranah pendidikan yang mengahapkan pembiasan kesadaran kolektif yang dapat menumbuhkan moral yang baik pula. perlu adanya penerapan dan pelestarian agar moral yang telah terbentuk dapat terus bertahan, moral yang baik merupakan modal utama yang harus dimiliki anak bangsa, dengan 
moral yang baik itu artinya memiliki kemandirian, kedisplinan, kejujuran, kemauan untuk maju dan itu dapat memajukan Negara ini.

\section{PENERAPAN REVOLUSI MENTAL DALAM MEMBENTUK KARAKTER}

Penerapan revolusi mental memiliki filosofi yang harus benar-benar bisa diterapkan, khususnya dalam dunia pendidikan dengan sebaik-baiknya. Contoh konkret yaitu jujur, di era milenial sekarang ini kejujuran sangat sulit untuk bisa diterapkan. Teknologi semakin berkembang, kekhawatiran praktik plagiat yang dilakukan oleh siswa dalam pembuatan karya ilmiah akan semakin marak. Kehadiran revolusi mental di era milenial ini apakah solusi yang tepat untuk meminimalisir siswa dalam berprilaku tidak sesuai dengan aturan, atau justru kehadiran revulusi mental semakin terpinggirkan akibat semakin berkembangnya teknologi.

Pendidikan adalah usaha sadar dan mempunyai sistem, yang di jadikan suatu tindakan oleh pendidik terhadap peserta didik sehingga membentuk sifat dan tabiat yang selaras dengan tujuan pendidikan. (Achmad Munib, 2004:34 dalam Daryanto 1:2010)

Pendidikan bisa dinyatakan juga sebagai bagian dari perubahan sosial, yang memiliki dua fungsi yang dapat di katakana sebagai pertentangan, di satu sisi pendidikan berusaha mempertahankan sistem sosial yang ada, dan sisi lain pendidikan juga di tuntut untuk membuat suatu perubahan sosial dan transformasi dunia yang lebih adil, keadaan ini di karena posisi masyararakat yang tidak statis atau karena keadaan masyarakat yang dinamis mengikuti perkembangan dan perubahan, dan pendidikan juga di haruskan dapat membuat individu dapat menghadapi perubahan sosial yang terjadi itu merupakan tantanan yang sangat berat, pendidikan harus berani untuk merombak sistem yang terus berkembang yang tentunya memiliki resiko sosial yang besar. (Martono, 194:2012)

Penerapan pendidikan revolusi mental bukan sekedar mengembangkan pembentukan karakter bagi para siswa, melainkan seluruh individu yang terlibat dalam dunia pendidikan. Pendidik merupakan aktor utama bagi berlangsungnya proses revolusi mental, sebab dengan pemahaman diri yang baik, memahami pemahaman akan konteks yang disadari akan semakin memungkinkan pendidik menjadi pendidik karakter yang efektif.

Revolusi mental dan pendidikan karakter merupakan dua mata pisau yang tidak dapat dipisahkan satu sama lainnya. Jika kedua paradigma itu diterapkan dengan baik dalam dunia pendidikan, maka pendidikan di Indonesia akan sesuai dengan apa yang dicita-citakan bangsa Indonesia sebelumnya. Siswa tidak selamanya menerima materi yang diberikan oleh guru, tetapi sangat diperlukan juga penanaman nilai karakter yang diberikan guru terhadap siswa. Pendidikan karakter secara sederhana bertujuan membentuk karakter siswa sesuai dengan apa yang kita inginkan. Karakter ini, menurut saya, terutama adalah karakter moral seperti 
disampaikan oleh Lickona, "ketika kita berpikir tentang karakter macam apa yang kita inginkan terjadi dalam anak-anak kita, jelaslah bahwa kita ingin agar mereka dapat menilai apa yang benar, menjaga sungguh-sungguh apa yang benar, dan kemudian melakukan apa yang mereka yakini sebagai sesuatu yang benar bahkan ketika mereka menghadapi tekanan dari luar dan godaan dari dalam diri mereka sendiri.

Tujuan pendidikan revolusi mental selain untuk merubah perilaku manusia menjadi lebih baik, yaitu membentuk karakter siswa seperti yang kita harapkan, maka pertanyaan berikutnya adalah karakter siswa seperti apa yang ingin kita bentuk? apa pemahaman dan pengertian dari karakter yang ingin dibentuk tadi?

Pendidikan karakter bertujuan membentuk individu menjadi pelaku perubahan bagi dirinya sendiri dan masyarakatnya dalam terang praksis perilaku berkeutamaan. Jadi pendidikan karakter secara umum ingin mengajak kita mengerti bahwa pendidikan karakter utuh dan menyeluruh ingin membentuk individu, terutama siswa, yang bukan sekedar memiliki kecerdasan unggul, berbudi baik, namun juga mesti dapat menjadi pelaku perubahan bagi diri sendiri dan bagi masyarakat. Dimensi transformasi sosial inilah yang selama ini hilang dalam dunia pendidikan kita.

Pada intinya paradigma revolusi mental adalah perubahan besar dengan mengembangkan mentalitas, dengan 3 aspek inti internal yaitu cara berpikir, spiritual/meyakini dan bersikap. Dengan ketiga aspek inti tersebut kita dapat menjadi kepribadian yang baik, selanjutnya setelah memiliki kepribadian yang baik maka kita perlu faktor dari luar yang mendukung seperti di terapkannya pendidikan revolusi mental di lingkungan sekolah seperti membaca doa sebelum belajar, menerapkan kedisiplinan, pendidik mengajarkan cara analisis yang baik untuk memecahkan suatu masalah, dan menjadi tauladan atau contoh yang baik agar peserta didik dapat bersikap baik pula. Dengan memiliki aspek internal dan eksternal khususnya sekolah dan pendidikan melalui revolusi mentalnya maka akan semakin cepat terwujud moral yang baik. (Maragustam, Vol. XII. No 22015 hal. 164)

\section{PERAN KURIKULUM}

Penerapan revolusi mental melibatkan peran kurikulum yang mendukung, peran kurikulum dalam pendidikan merupakan jantungnya pendidikan. Kurikulum memberikan corak dalam wajah pendidikan suatu masyarakat itu artinya kurikulum yang di tetapkan dalam pendidikan merupakan suatu ciri pembentukan masyarakatnya. Kurikulum bukan hanya sebagai substansi dan sistem secara kecil, tetapi kurikulum juga melibatkan relasirelasi antar penguasa yang memiliki kepentingan didalamnya. Dan juga berkaitan anatara 
hubungan nega dan sekolah, kurikulum menjadi jalan strategis dalam level makro yang berhubungan dengan berbagai agen kepentingan. (Hidayat, 86:2011)

\section{PENDEKATAN KOGNITIF DALAM PENERAPAN REVOLUSI MENTAL}

Dalam penerapan pendidikan revolusi mental perlu di lakukannya pendekatan kognitif yang menekankan dalam proses internal dan mental manusia, tindakan manusia tidak dapat di ukur dengan melihat hasil tindakannya saja tetapi harus melibatkan mental seperti kesenjangan, motivasi seseorang melakukan tindakan, keyakinan dan lain sebagainya. Dalam pendekatan ini menekankan pada pendekatan mental bukan bersipat jasmani. Jadi sebagai pendidik kita harus melakukan pendekatan mental terlebih dahulu dengan peserta didik. (Syah, 114:2014)

\section{KESIMPULAN}

Pada intinya paradigma revolusi mental adalah perubahan besar dengan mengembangkan mentalitas, dengan 3 aspek inti internal yaitu cara berpikir, spiritual/meyakini dan bersikap. Dengan ketiga aspek inti tersebut kita dapat menjadi kepribadian yang baik, selanjutnya setelah memiliki kepribadian yang baik maka kita perlu faktor dari luar yang mendukung seperti di terapkannya pendidikan revolusi mental di lingkungan sekolah seperti membaca doa sebelum belajar, menerapkan kedisiplinan, pendidik mengajarkan cara analisis yang baik untuk memecahkan suatu masalah, dan menjadi tauladan atau contoh yang baik agar peserta didik dapat bersikap baik pula.

Penerapan pendidikan revolusi mental bukan sekedar mengembangkan pembentukan karakter bagi para siswa, melainkan seluruh individu yang terlibat dalam dunia pendidikan. Pendidik merupakan aktor utama bagi berlangsungnya proses revolusi mental, sebab dengan pemahaman diri yang baik, memahami pemahaman akan konteks yang disadari akan semakin memungkinkan pendidik menjadi pendidik karakter yang efektif.

\section{DAFTAR PUSTAKA}

Daryanto. 2010. Media pembelajaran. Bandung. CV yrama widya

Hidayat, Rakhmat. 2011. Pengantar Sosiologi Kurikulum. Jakarta. Rajawali Pers.

Margustam, 2015. Jurnal pendidikan agama islam (paradigm revolusi mental dalam pembenatukan karakter bangsa berbasis seintegritas islam dan filsafat pendidikan. Vol. XII, No. 2, Desember 2015.

Martono, Nanang. 2012. Sosiologi Perubahan Sosial(Perspektif Klasik, Modern, Postmodern, Dan Poskolonial) : Jakarta. Rajawali Pers 
Ritzer, George. 2012. Teori Sosiologi (Dari Teori Sosiologi Klasik Sampai Perkembangan Mutakhir Teori Sosial Postmodern). Bantul. Kreasi Wacana

Syah, Muhibbin. 2010. Psikologi Pendidikan(Dengan Pendekatan Baru). Bandung. PT Rosdakarya.

Juanda, S,. Afrizal, S., \& Hardiyanti. 2019. Jurnal Hermeneutika: Pendidikan Moral Melalui Tradisi Kesantrian di Pondok Pesantren Salafiyah Al-Fathaniyah Kota Serang. Vol 5, No 2. 